\title{
Political Attitudes of the American Professoriate Toward the Persian Gulf War
}

\author{
Gary Shepherd, Oakland University \\ Gordon Shepherd, University of Central Arkansas
}

\begin{abstract}
Based on a national random sample of 657 college professors, indexes were constructed to measure faculty support for U.S. military involvement in the 1991 Persian Gulf War (IRAQHAWK), justifications for U.S. military actions (USJUST), opposition to the war (IRAQDOVE), justifications for Iraqi actions (IRAQJUST), and willingness to consider active protest against the war (GULFPROTEST). Principal findings showed that (1) college professors were less supportive of the war than the American public as a whole, (2) faculty liberalism was associated with greater disapproval of the war, (3) faculty responses to the war varied by academic discipline, with those in the social sciences and humanities least likely to support the war, and (4) cohort effects were relatively weak, but older faculty were most likely to support the war. Implications of this last result are discussed with respect to a statistically dominant cohort of Vietnam generation faculty in contemporary academia.
\end{abstract}

In the preface to their landmark study of the politics of American College professors, Ladd and Lipset (1975) comment on the political ascension of university academics and intellectuals in modern history. They argue that as an occupational category college professors have come to occupy a central place in the political structure of advanced industrial and postindustrial societies. College professors not only instruct the young in specialized areas of knowledge necessary for the continued functioning of modern society, they also advise leaders of government and industry and contribute importantly to social change through the discovery and analysis of new ideas. Consequently, the political orientations of academics and their apprentices merit serious study and attention. In Ladd and Lipset's words, "no examination of American politics ... can properly ignore the place of those groups in the population located around the application of trained intelligence" (1975, xiv).

Ladd and Lipset's study was based on national surveys of the American professoriate conducted in 1969 and 1972, during the throes of the Vietnam War, a time when many American universities had become centers of the counter-culture and antiwar movement. Among other things, their findings

GARY SHEPHERD is Associate Professor of Sociology at Oakland University.

GORDON SHEPHERD is Professor of Sociology at the University of Central Arkansas.

The American Review of Politics, Vol. 14, Spring, 1993: 71-95

(C)1993 The American Review of Politics 
showed that the political orientations of college faculty were significantly more liberal than those of other occupational groups. This was true not only of academics during the Vietnam era: data from other studies support similar conclusions about the relatively liberal views of college professors in American society throughout the twentieth century, especially during times of national turmoil and conflict (Lazarsfeld and Thielens 1958; May 1963; Nettl 1969; Bayer 1971; Austin et al. 1975; Carnegie Foundation 1989).

The relative liberalism of academic intellectuals may be attributed, in part, to the nature of their training and the expectations of their disciplines, which typically place a premium on questioning, innovation, and the critical analysis of conventional forms of thought and practice (Shils 1983; Fuller 1990; Gless and Hernstein 1990). However, beyond these generalizations, Ladd and Lipset's analysis also drew attention to the diversity and range of political values within the ranks of the professoriate. They demonstrated how varying political attitudes were linked systematically to structural divisions in academia based on such factors as the types of academic institutions in which individuals trained and worked, the subject matter of their particular disciplines and fields of specialization, and their age cohort associations. Thus, for example, Ladd and Lipset's data showed that faculty and students at elite colleges and major research universities were more liberal than those at primarily teaching institutions; that productive scholars and scientists were more liberal, on average, than those who were not engaged actively in doing research; that faculty and students in social science disciplines and humanities were more liberal than those in physical science, business, or any applied fields of study such as engineering, nursing, or education; and that younger faculty typically were more liberal than older faculty (for similar findings from studies of the same era, see Cole and Adamsons 1970; Bass 1971; Wilson 1979).

The heyday of student activism and massive campus protest so characteristic of the Civil Rights and Vietnam eras gave way in the 1970s to a national conservative retrenchment which continues to set the agenda for much of the political discourse in the United States today (Crawford 1980; Kayden and Mahe 1986; Newman 1989; Polsby and Wildavsky 1988; Wills 1990; Diggins 1992; Dionne 1992). At the same time a substantial fraction of the national professoriate now is comprised of individuals who were either undergraduate or graduate students during the tumultuous 1960s. (Figures below indicate that approximately one out of every two contemporary American college professors was a student during the period of the Vietnam War).

What are the current political values of the contemporary American professoriate? Do college professors continue to be, as in the past, more 
liberal than most other groups in American society, or have their collective political views changed with the times? In particular, what are the contemporary political values of those large numbers of faculty who came of academic age during the 1960s? Conservative critics of the academy complain that the Vietnam cohort imbibed so deeply of the cultural and political dissent rampant in their own student era that even today, compared to their colleagues of other generations, they particularly stand out as collective exponents of liberal-radical values. In contrast, some liberal observers bemoan that faculty who once were student activists have fallen afoul of the "Big Chill," abandoning their youthful idealism as they have become middle aged, tenured professors.

Previous studies that have focused on the Vietnam War as a generational watershed in contemporary American political history offer somewhat mixed results. Holsti and Rosenau's (1980, 1984, 1990) empirical analyses of the foreign policy views of American leadership "elites" (in business, politics, education, religion, the military, etc.) indicated that there were moderate differences between Vietnam generation elites and others on some political issues, but that occupation was linked much more significantly to variations in political preferences than were generational attachments. Thus, taking into account elite occupations, political differences within generations were found to be far greater than political differences between generations. Wittkopf's (1990) study of changing public attitudes toward American foreign policy confirmed that the Vietnam War was a political turning point for both elites and masses in the United States, stimulating an erosion of the Cold War era foreign policy consensus to resist the global spread of communism, including resort to military intervention if necessary. Today, according to Wittkopf, the foreign policy public in the United States is deeply split ideologically between accommodationists and hardliners, whose political views have been shaped substantially by the military failure and political recriminations of the Vietnam War. The 1991 Persian Gulf War between the United States and Iraq afforded a new international political context in which to examine the ideological values of the contemporary professoriate as an elite sector of American society. Although armed hostilities ultimately turned out to be brief in duration and lopsided in outcome, the Persian Gulf conflict nevertheless generated the greatest amount of military mobilization and sustained war tension experienced by Americans since the Vietnam War. Indeed, memories and lessons of Vietnam - their meanings and implications disputed by conservative and liberal commentators - provided a constant backdrop for public debate up to the actual commencement of combat. The war itself proved enormously popular with the great majority of Americans: national opinion polls consistently 
reported around 80 percent support for U.S. and U.N. military actions from the beginning to the end of armed hostilities (cf. reports from the Gallup Poll Monthly, January through March 1991). During such a time of general patriotic ferver, did the faculties of America's colleges and universities follow suit? Or did they tend toward a more traditional professorial pattern of campus dissent?

In this study we report findings from a national survey of U.S. college and university faculties that address the questions raised above. In particular, we will focus our attention on the nature of faculty responses to the Persian Gulf War and in the process try to illuminate the broader political characteristics of the contemporary American professoriate.

\section{Methods and Description of Variables}

\section{Sample}

Our target population of the American professoriate was operationalized through the use of the 1991 National Faculty Directory. This comprehensive directory includes a listing of approximately 600,000 current names and addresses of faculty at both U.S. and Canadian institutions of higher education. Elimination of Canadian and all two year institutions from consideration produced a final sampling frame that itemized the overwhelming majority of faculty members affiliated with four year colleges and universities in the United States. From this sampling frame we obtained a computer-generated random selection of 1300 faculty names and addresses for our mailed survey.

An 83-item questionnaire was mailed to these 1300 faculty on January 15, 1991, just one day prior to the initial bombing of Baghdad by U.S. war planes. Two waves of reminder notices and replacement questionnaires were mailed to nonrespondents on January 28 and on February 25. Ultimately, 657 completed questionnaires were returned to us, yielding a response rate of 51 percent.

Our final sample included respondents from all 50 states and from Washington D.C., representing 390 different colleges and universities. The demographic characteristics of the sample closely matched the statistical profile of the American professoriate summarized in a Carnegie study (1989) and recent publications of the National Center for Education Statistics (1991, 1992). Males constituted 70 percent of the sample, females 30 percent. The mean age of respondents was 48 . Fifty-eight percent of the faculty in the sample were tenured, while the distribution of academic rank was 34 percent full professor, 30 percent associate professor, 26 percent 
assistant professor, and 10 percent instructor/lecturer. Jewish faculty were the largest ( 8 percent) ethnic minority represented in the sample; African Americans constituted 2 percent, Hispanics 1 percent, and various Asian groups totaled 3 percent. Ninety-five percent of the faculty in the sample were U.S. citizens. Twenty percent of all respondents reported having either family members or friends deployed for military duty in the Persian Gulf. Ninety percent of the sample completed questionnaires prior to the U.S. ground offensive which began on February 23, 1991.

\section{Measurement of Dependent Variables}

Our questionnaire was designed to measure three broad categories of dependent variables concerning conflict in the Persian Gulf: (1) attitudes about a variety of military actions (both taken and contemplated) against Iraq, (2) justifications for U.S. versus Iraqi actions, and (3) willingness to engage in public protest of U.S. war policies. The military action category consisted of ten Likert items (5-point). Seven of these items focused on aggressive military decisions (e.g., degree of support/opposition to "the deployment of a massive U.S. military force to Saudi Arabia following Iraq's invasion of Kuwait," or "first strike military action by U.S. forces to destroy Iraq's military capability"). The remaining three items in this category emphasized lessening of U.S. military involvement (e.g., degree of support/opposition to "substantial decreases in the troop strength and equipment of U.S. military forces in Saudi Arabia").

The distinction between aggressive and withdrawal items in the military action category led us to construct two sub-indexes: IRAQHAWK, based on the mean score of the first seven questionnaire items, and IRAQDOVE, based on the mean score of the last three items. Both indexes demonstrated an acceptable degree of homogeneity. The 21 inter-item correlations for IRAQHAWK ranged from a low of .54 to a high of .85 , with an overall mean inter-item correlation of .66 and an alpha reliability coefficient of .93. The three inter-item correlations for IRAQDOVE yielded an overall mean of .56 and an alpha of .80 .

The justification category also consisted of ten Likert items (5-point), seven of which focused on the rationale for U.S. military intervention (e.g., degree of approval/disapproval of such statements as "The deployment of U.S. military forces was justified to protect the access of industrial nations to oil reserves in the Middle East," or to "deter further Iraqi military aggression in the Middle East"). The remaining three items stated rationales for Iraqi actions (e.g., "The invasion and annexation of Kuwait by Iraq was based on legitimate territorial claims against Kuwait"). We again created two 
index measures based on these category subdistinctions: USJUST, defined by the mean score of the first seven justification items, and IRAQJUST, defined by the mean score of the last three justification items. The inter-item correlations of these indexes were not quite as strong, overall, as those obtained for the military action indexes. The lowest among 21 inter-item correlations for USJUST was .36, the highest was .67, and the mean correlation was .52 , with an alpha reliability coefficient of .89 . The mean correlation among the three items of IRAQJUST was .37 with an alpha of .63.

Public Protest, our final category of dependent variables, was measured by two 4-point questionnaire items whose combined score yielded an index called GULFPROTEST. Both index items asked whether, and with what degree of certainty, the respondent would engage in demonstrations against the deployment of U.S. troops to Saudi Arabia. However, one question specified legal protest while the other specified civil disobedience. The correlation between these two items was .74.

To establish the construct validity of our various index variables we intercorrelated the index scores themselves. Table 1 shows a desirable pattern of results: IRAQHAWK is strongly and positively correlated with USJUST but shows a strong negative correlation with both IRAQDOVE and IRAQJUST. Conversely, IRAQDOVE is strongly and positively correlated with IRAQJUST and GULFPROTEST, but shows a strong negative correlation with USJUST. Finally, IRAQJUST is strongly and positively correlated with GULFPROTEST, while simultaneously being strongly and negatively correlated with both IRAQHAWK and USJUST.

Thus, our five index measures not only show generally good internal consistency but also appropriate discriminant capacity; their empirical interrelationships correspond with conceptual expectations. We will employ these measures as our dependent variables throughout the remainder of this analysis.

Table 1. Intercorrelations Between Persian Gulf War Index Measures

\begin{tabular}{lccccc}
\hline & IRAQHAWK & USJUST & IRAQDOVE & IRAQJUST & GULFPROTEST \\
\hline IRAQHAWK & - & & & & \\
USJUST & .83 & - & & & \\
IRAQDOVE & -.81 & -.76 & - & - & \\
IRAQJUST & -.67 & -.63 & .64 & - \\
GULFPROTEST & -.71 & -.65 & .71 & .56 & -
\end{tabular}

Note: All correlations significant at $\mathrm{p}<.001$. 


\section{Distribution of Dependent Variables}

Table 2 summarizes the mean scores and standard deviations of our five index variables for the faculty as a whole. The first four indexes (IRAQHAWK through IRAQJUST) share the same score range of 1.0 to 5.0 (where 5.0 indicates the strongest possible expression of support, 1.0 indicates the strongest possible expression of opposition, and 3.0 represents an undecided response). GULFPROTEST has a score range of 0.0 to 9.0, in which 0.0 represents "no, definitely not" responses to the possibility of participating in both legal protest and civil disobedience actions. Conversely, a score of 9.0 represents "yes, definitely" responses to willing participation in both legal protest and civil disobedience. Thus, GULFPROTEST scores that range between 0.0 and 9.0 may be interpreted as representing varying degrees of willingness to consider the possibility of some sort of personal involvement in anti-war activities.

Table 2. Means and Standard Deviations for Persian Gulf War Index Measures

\begin{tabular}{|c|c|c|c|}
\hline & Means & Std. Dev. & $\begin{array}{l}\text { Percent } 4.0 \text { or }> \\
\text { ("Favor") }\end{array}$ \\
\hline IRAQHAWK & 3.36 & 1.21 & $40 \%$ \\
\hline IRAQDOVE & 2.64 & 1.13 & 16 \\
\hline USJUST & 3.33 & 1.00 & 33 \\
\hline IRAQJUST & 2.25 & 0.88 & 5 \\
\hline GULFPROTEST & $1.92 *$ & 2.64 & $46^{* *}$ \\
\hline \multicolumn{4}{|c|}{$\begin{array}{l}\text { * Mean based on score range of } 0.0 \text { to } 9.0 \text {. All other scores range from } 1.0 \text { to } 5.0 \text {. } \\
\text { **Reflects percent who did not rule out the possibility of participating in either legal } \\
\text { protest or civil disobedience. }\end{array}$} \\
\hline
\end{tabular}

With Index values of 3.4 and 3.3, respectively, the means of both IRAQHAWK and USJUST fall between undecided and support for the war effort on our five point scale. Two-fifths of the faculty scored 4.0 or higher on IRAQHAWK and only one-third scored 4.0 or higher on USJUST. Thus, our measures show only a moderate hawkishness on the part of the professoriate as a whole, in terms of favoring war against Iraq and justifying the United States for so doing.

IRAQDOVE and IRAQJUST, our oppositional indexes on war with Iraq, inversely reflect our support measures. With index values of 2.6 and 2.3, 
respectively, the means of both IRAQDOVE and IRAQJUST fall between undecided and disagreement with anti-war protest objectives. At the same time, only 16 percent of our faculty sample scored 4.0 or higher on IRAQDOVE, and a mere 5 percent scored 4.0 or higher on IRAQJUST. These results indicate that although a fair amount of ambivalence toward the war existed, faculty overall were relatively reluctant to advocate a withdrawal of American military forces or acknowledge the legitimacy of Iraqi claims. (Many faculty who were opposed to U.S. war aims were nonetheless unsympathetic to Iraqi policies and actions related to the annexation of Kuwait.)

Our survey of faculty willingness to consider taking some sort of action to protest U.S. military intervention in the Persian Gulf produced a GULFPROTEST mean of 1.9 on a scale that ranges between 0.0 and 9.0. While this may seem like a relatively low score, it must be recalled that any value beyond 0.0 on this particular index indicates some willingness to entertain the possibility of participating in a protest activity, or, at least, an unwillingness to rule out the possibility of protest. Considered in this light, it is worth looking at the distribution for both the legal demonstration and civil disobedience items on which GULFPROTEST is based (see Table 3). Only 12 percent of the faculty responded yes, without reservation, that they would be willing to engage in legal protest against the war, and only a tiny proportion of 4 percent said they would willingly engage in civil disobedience. But perhaps the most remarkable result here is that only a little more than half of our respondents said they definitely would not consider legal protest against the war, and only two-thirds would not consider civil disobedience. In short, substantial fractions of the professoriate (45 and 32 percent respectively) did not rule out the possibility of becoming involved in legal demonstrations or even civil disobedience to protest U.S. military actions in the Persian Gulf.

Table 3. Distribution of Faculty Responses to the Possibility of Legal Protest and Civil Disobedience Against the Persian Gulf War

\begin{tabular}{lcc}
\hline & Legal Protest & Civil Disobedience \\
\hline Definitely not & $55 \%$ & $68 \%$ \\
Don't know & 13 & 16 \\
Perhaps & 20 & 12 \\
Yes, definitely & 12 & 4 \\
\hline
\end{tabular}


To be adequately appreciated, these results must be viewed in the context of widespread anti-Iraq sentiments and the popularity of the war among the general U.S. public, as consistently reported by many national opinion polls. Although our index scores are not directly comparable to the single item measures typically employed in most polls, the public disposition revealed by national opinion polls just prior to the outbreak of combat and during the short duration of the war itself cannot be gainsayed: there was overwhelming public support for the military solutions being used to resolve the conflict. Throughout both the air war and ground offensive, Gallup polls consistently reported 79 to 81 percent public approval of the use of military force to expel the Iraqis from Kuwait. In late February and early March, 1991, George Bush was given a 92 percent approval rating for his handling of the Persian Gulf conflict and, in March, Bush received an overall approval rating of 89 percent, the highest in presidential polling history, according to Gallup (see Gallup Poll Monthly, January-March 1991). Our faculty index scores do not reflect this magnitude of enthusiasm and, in fact, indicate a certain amount of dissent. In this larger context the professoriate emerged as a segment of society whose collective political and moral attitudes about the war differed substantially from those of the American populace as a whole.

\section{Measurement and Distribution of Independent Variables}

While we may characterize college faculty reactions to the Persian Gulf War as considerably more ambivalent and inclined to dissent to some degree against the war in comparison to the overwhelming approval of U.S. military action expressed by most segments of American society, we also must take note of the substantial variations of opinion within the professoriate. Here, we limit our attention to the examination of faculty political orientations, academic disciplines, and age cohorts, as likely sources of this variation. Important variables not considered in this paper include the institutional characteristics of the schools at which faculty received their academic training and at which they currently teach, regional differences, and gender differences.

First, we will describe the measurement and distribution of the selected independent variables in the sample. Then, we will analyze their statistical association with the above index measures of support for/opposition to U.S. military intervention in the Persian Gulf.

\section{Politics}

In order to measure variation in faculty political orientations we have used four indicators: political party identification, presidential vote in 1988, 
and self ascribed political positions from left wing to right wing on both social and economic issues, as shown in Table 4.

Approximately three-fifths (62 percent) of the faculty identified with the Democratic Party and only one-quarter labeled themselves as Republicans. A relatively small percentage ( 8 percent) described their political party identification as "other" and only 4 percent said they had no party preference. Based on correlations with other political measures in our survey, we have concluded that the majority of academics whose party preference lies outside the dominant two party system in American politics tend to be leftist in their political orientations, while the political values of those not indicating any party preference appear, on average, to correspond most closely to Republican positions.

Table 4. Distribution of Faculty by Political Indicators, Academic Fields, and Cohort Categories

1. Political Party Identification

Democrats

Republicans

Other

None

2. 1988 Presidential Vote Michael Dukakis

George Bush

Other

None

3. Position on Economic Issues

Radical Left

Liberal

Moderate Liberal

Moderate Conservative

Conservative

Radical Right

$62 \%$
26
8
4

57

34

4

5

\section{6}

26

31

27

9

.2

4. Position on Social Issues

$\begin{array}{lr}\text { Radical Left } & 8 \\ \text { Liberal } & 37 \\ \text { Moderate Liberal } & 26 \\ \text { Moderate Conservative } & 18 \\ \text { Conservative } & 10 \\ \text { Radical Right } & .2\end{array}$

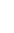

5. Academic Fields

$\begin{array}{ll}\text { Humanities } & 30 \% \\ \text { Science and Mathematics } & 26 \\ \text { Social Science } & 21 \\ \text { Business } & 14 \\ \text { Education } & 10\end{array}$

6. Age Cohorts

Pre-Vietnam (over 50 yrs.) 37

Vietnam (38 to 50 yrs.) $\quad 44$

Post-Vietnam

(less than 38 yrs.) 20

7. Academic Degree Cohorts

Pre-Vietnam (prior to 1966) 25

Vietnam (between 1966 and 1975)

Post-Vietnam (after 1975) 
Faculty voting patterns in the 1988 presidential election were generally consistent with stated political party preference, although we do see a small percentage of Democratic defection in favor of George Bush over Michael Dukakis. Overall, however, a solid majority (57 percent) of American academics gave their vote to Dukakis, compared to the 46 percent he received from the American electorate at large (Nelson 1989). These patterns are consistent with previous surveys of faculty political preference and confirm that, as a whole, American academics continue to represent a reliable constituency of the national Democratic Party. Our findings also confirm that academics are far more likely to exercise their political franchise than is the general electorate: only 5 percent of our faculty sample did not vote in the 1988 presidential election, compared to the alarmingly large fraction (50 percent) of the national electorate who failed to vote in that election (Barone and Ujifusa 1990).

In a related vein, we see that when faculty were asked to identify their typical political views on most economic and social issues, a substantial majority of 57 to 63 percent claimed either liberal or moderately liberal positions. In addition, a small but noteworthy fraction of 6 to 8 percent identified their political views as radical left. In contrast, only 9 to 10 percent of the faculty characterized themselves unreservedly as conservatives and there was virtually no identification with the radical right label on either economic or social grounds. If we combine moderate liberals with moderate conservatives in a "middle of the road" or centrist category we get a somewhat modified picture of faculty ideological tendencies. A majority (58 percent) take a more or less centrist position on current economic issues. At the same time only 44 percent are middle of the road on social issues. Correspondingly, those who claim left-liberal views increase from 33 percent of the faculty on economic matters to 46 percent who are left-liberal in their social concerns. Thus, while centrist attitudes predominate toward economics, our data show that the professoriate is ideologically more inclined toward the left on questions of social policy.

\section{Academic Field}

Consistent with earlier studies of academia, we propose that variations in academic discipline and training can represent an important factor in linking faculty political views with their attitudes toward the Persian Gulf War.

The 657 respondents to our survey represented 73 different academic fields, which we reduced to a set of 5 general areas: Science and Mathematics, Social Science, Humanities, Business, and Education. The Science and Mathematics category consisted of the largest number of specific 
disciplines, ranging from anatomy to zoology, and included all engineering and medical sciences, as well as all mathematics and computer science fields. Social Science disciplines ranged from anthropology to urban studies, and included history and psychology. Humanities disciplines ranged from art to theater, and included all language fields, philosophy, music, and religious studies. In Business our sample was represented by accounting, advertising, finance and banking, marketing, and management. Finally, subfields of Education included educational administration, home economics, library science, and physical education, as well as any form of primary or secondary education.

Shifting attention to the distribution of faculty within general academic fields, we see that 3 out of 10 respondents in our sample taught in the Humanities, 1 out of 4 was in a Science or Mathematics related discipline, 1 out of 5 was in the Social Sciences, and the remaining quarter of the faculty was divided between those who taught in Business fields and those in Education, respectively. It should be pointed out that, taken together, professors in Humanities and Social Science - putatively the most liberal disciplines - constituted precisely one-half of our sample of the American professoriate.

\section{Cohort Categories}

Given the data obtained in our survey, there are two different ways for us to define faculty cohort groups in order to test hypotheses about cohort effects on our respondents' political orientations and their reactions to the Persian Gulf War. One way is simply to look at the distribution of respondent ages and identify a series of cutoff points along an age continuum. The other way is to identify a set of different time periods during which respondents actually were enrolled as college students - a major turning point in their academic careers.

In either case, since we are interested in designating a category of faculty who, as students, came of age during the Vietnam War years, we need to specify a relevant length of time in American history during which the Vietnam War was a galvanizing public issue. For this study we have selected the decade between 1965-66 and 1974-75. Although the Vietnam War was gradually becoming an issue in American Politics in the late 1950s and early 1960s, it was not until 1965, when the decision was made to end student draft deferments and engage in a massive escalation of American ground forces in Vietnam, that the war became a focus for national student protest (Sale 1973; Gitlin 1987). Public protest against the war peaked in the late 1960s and early 1970s. Subsequently, peace talks were pursued and 
American troops gradually were withdrawn, but, arguably, the Vietnam era of student dissent did not really end until the final withdrawal of all U.S. military forces from Saigon in April, 1975.

Age

The age distribution of respondents in our sample ranged widely, from 25 to 77 years of age. But the mean age was 47 and modal age was 42 . This suggests that the average college professor today was, in all probability, a student during the heyday of the Vietnam War.

Any specification of a particular age cohort inevitably requires some arbitrary decisions. As upper and lower age limits for defining a Vietnam cohort, we designated 50 years and 38 years of age respectively. Those who were 50 years old at the time of our survey would have been born in 1941 and typically would have graduated from high school in 1959. As underclassmen in college they would witness the inauguration of John F. Kennedy as President of the United States, and, concurrently, they would see the commencement and rapid spread of "sit-ins," freedom rides, and other imaginative civil rights tactics of civil disobedience. In contrast, those who were 38 years old at the time of our survey would have been born in 1953 and typically would have graduated from high school in 1971, one year after student anti-Vietnam war demonstrators were shot by a unit of the Ohio National Guard at Kent State University. As college seniors, they would see President Gerald R. Ford announce the end of America's military involvement in Vietnam. While this particular age range may leave out a few of the earliest student activists or a few others who might have been politically precocious before entering college, we would argue that it is a range that fairly embraces the vast majority of current faculty who came of age during the Vietnam era.

Thus defined, we see from Table 4 that over two-fifths (44 percent) of the faculty is comprised of a Vietnam cohort, representing the single largest segment of the contemporary professoriate. The remainder of the faculty is divided between those in a pre-Vietnam cohort ( 20 percent) who were older than 50 years of age at the time of the survey, and a post-Vietnam cohort of faculty (36 percent) whose ages were younger than 38 when the survey was taken.

\section{Date of Academic Degrees}

While age indicates one's generational position in society and therefore may serve as a general indicator of generational differences in world view, 
it may be argued that the most important factor for understanding variation in student views is not age per se, but which student cohort groups individuals actually pass through over the course of their educational careers, regardless of their age. This allows for the possibility that either older or younger individuals may be part of the same student cohort, even though they may deviate from the age norms of their cohort group. It is an approach to cohort analysis that emphasizes the potential of student peer group influence on individuals' social perspectives, independent of age criteria per se. Thus, in our study, we have taken college graduation dates as a supplementary way to measure faculty cohort affiliations.

The median year in which faculty members in our sample obtained their undergraduate degrees was 1966, whereas the median year for highest graduate degree obtained was 1975 . Both figures confirm that the average faculty member today was enrolled as a college student at some point during the Vietnam War era.

Looking at the distribution of graduation dates we see that 35 percent of current faculty received their undergraduate degrees during the Vietnam War (between 1966 and 1975), while 32 percent obtained their highest graduate degree during this same span of time (see Table 5). Cross-classification of undergraduate and graduate degree dates yields a total of six cohort categories, as shown in the following table.

Table 5. Cross-Tabulation of Undergraduate Degree Cohorts by Graduate Degree Cohorts

\begin{tabular}{lccc}
\hline & \multicolumn{3}{c}{ Received Highest Graduate Degree } \\
& prior to & between & after \\
& 1966 & $1966-1975$ & 1975 \\
\hline Received Bachelor's Degree & & & \\
$\quad$ prior to 1966 & $15 \%$ & $22 \%$ & $9 \%$ \\
between 1966 and 1975 & & 10 & 25 \\
after 1975 & & & 19 \\
\hline
\end{tabular}

Based on these categories, the most comprehensive definition of a Vietnam cohort would include all current faculty who received either undergraduate degrees and/or graduate degrees during the period 1966-1975. Thus defined, this particular faculty cohort is indeed a statistically dominant group in academia today, representing close to three-fifths (57 percent) of the American professoriate. The remainder of the professoriate consists of a pre- 
Vietnam cohort of faculty who obtained all of their academic degrees prior to 1966 , a post-Vietnam cohort who received their degrees after 1975, and a somewhat anomalous cohort of faculty who were awarded undergraduate degrees prior to 1966 but did not go on to obtain their highest graduate degrees until sometime after 1975. Conceptually, this latter group cannot be classified unambiguously as part of either the pre- or post-Vietnam student cohorts. However, on the basis of empirical comparisons, the political values of this group correspond quite closely to those of the older faculty who had achieved all of their degrees prior to 1966-with whom, of course, they also share a more similar age range. For these reasons we made the decision to include this group of faculty with those of the pre-Vietnam cohort. Thus defined, the pre-Vietnam cohort of faculty who graduated from college prior to 1966 represents exactly one-quarter of the professoriate. This leaves a remainder of roughly one-fifth (19 percent) of current faculty who, on the basis of when they received their academic degrees, may be considered an entirely post-Vietnam cohort.

In summary, whether cohorts are defined according to age or by date of academic degrees, a Vietnam cohort of faculty predominates in contemporary academia. This is especially true when we consider degree dates.

\section{Analysis of Variance Results}

In Table 6, we have summarized the distribution of Gulf index means by all categories of our independent variables. In general, variables indicating faculty political orientations are related most strongly to support for or dissent from U.S. military policy toward Iraq, followed by academic field, with faculty cohort categories being weakest in their statistical associations.

Not surprisingly, Republican faculty were significantly more hawkish than Democrats and were least likely to express any protest sentiments. Those who identified "other" as their political party preference were somewhat more dovish than Democrats and had the highest mean GULFPROTEST score of any of the political party categories. Similarly, those who voted for George Bush in 1988 were most likely by far to support his military policies in the Gulf, while those voting for third party candidates ("other") were, again, even less likely than Democrats to support U.S. military action. Faculty views based on self-ascribed ideological positions toward both economic and social issues were consistent on every index measure: leftists systematically were more opposed to war than those on the right and, compared to political conservatives and moderates, were substantially more willing to consider protest action. Economic views were only 
86 | Gary Shepherd and Gordon Shepherd Table 6. One-Way Analysis of Variance: Gulf Index Means by
Faculty Politics, Academic Fields, and Cohort Categories

The asterisk $(*)$ identifies pairs of groups on the $\mathrm{Y}$ axis that differed significantly from each other at the .05 level based on Scheffe's multiple comparison procedure.

\begin{tabular}{|c|c|c|c|c|c|}
\hline Grand Means & $\begin{array}{l}\text { IHAWK } \\
(3.37)\end{array}$ & $\begin{array}{l}\text { UJUST } \\
(3.35)\end{array}$ & $\begin{array}{l}\text { IDOVE } \\
(2.63)\end{array}$ & $\begin{array}{l}\text { IJUST } \\
(2.24)\end{array}$ & $\begin{array}{c}\text { GPROTEST } \\
(1.90)\end{array}$ \\
\hline \multicolumn{6}{|l|}{ Party Identification } \\
\hline Democrats & 3.04 & 3.12 & 2.95 & 2.40 & 2.46 \\
\hline Republicans & 4.25 & 4.00 & 1.76 & 1.76 & 0.29 \\
\hline Other & 2.87 & 2.92 & 3.03 & 2.63 & 3.04 \\
\hline None & 3.73 & 3.50 & 2.53 & 2.09 & 1.26 \\
\hline eta & .45 & .40 & .47 & .24 & .38 \\
\hline F value & 55.44 & 38.99 & 56.21 & 12.57 & 34.49 \\
\hline sig of $F$ & .0000 & .0000 & .0000 & .0000 & .0000 \\
\hline
\end{tabular}

*Republicans vs. Democrats and Others on all Gulf indexes.

Democrats vs. None on IRAQHAWK.

Other vs. None on IRAQHAWK.

\begin{tabular}{|c|c|c|c|c|c|}
\hline \multicolumn{6}{|l|}{1988 Vote } \\
\hline Dukakis & 2.97 & 3.08 & 3.03 & 2.41 & 2.66 \\
\hline Bush & 4.23 & 4.00 & 1.82 & 1.78 & 0.35 \\
\hline Other & 2.54 & 2.52 & 3.44 & 3.17 & 3.74 \\
\hline None & 2.95 & 2.87 & 2.91 & 2.63 & 2.71 \\
\hline & .51 & .48 & .52 & .41 & .43 \\
\hline & 71.39 & 60.39 & 74.93 & 42.63 & 47.34 \\
\hline & .0000 & .0000 & .0000 & .0000 & .0000 \\
\hline
\end{tabular}

*Bush voters vs. Dukakis, Other, and None on all Gulf indexes.

Dukakis voters vs. Other on USJUST and IRAQJUST.

\begin{tabular}{|c|c|c|c|c|c|}
\hline \multicolumn{6}{|l|}{ Economic Views } \\
\hline Leftist & 2.46 & 2.65 & 3.47 & 2.71 & 3.90 \\
\hline Centrist & 3.71 & 3.59 & 2.35 & 2.08 & 1.18 \\
\hline Rightist & 4.38 & 4.00 & 1.72 & 1.72 & 0.07 \\
\hline eta & .55 & .49 & .52 & .38 & .52 \\
\hline F value & 131.27 & 94.92 & 114.33 & 51.91 & 115.88 \\
\hline sig of $F$ & .0000 & .0000 & .0000 & .0000 & .0000 \\
\hline
\end{tabular}


Table 6 (continued)

\begin{tabular}{lrrrrr} 
& IHAWK & UJUST & IDOVE & IJUST & GPROTEST \\
\hline $\begin{array}{lrrrrr}\text { Social Views } \\
\text { Leftist }\end{array}$ & & & & & \\
$\quad \begin{array}{l}\text { Centrist } \\
\text { Rightist }\end{array}$ & 2.69 & 2.83 & 3.30 & 2.56 & 3.40 \\
\cline { 2 - 6 } & 3.87 & 3.70 & 2.19 & 2.01 & 0.87 \\
eta & 4.33 & 4.01 & 1.67 & 1.81 & 0.10 \\
F value & .54 & .47 & .55 & .34 & .51 \\
sig of F & 122.75 & 87.23 & 129.18 & 40.13 & 107.10 \\
& .0000 & .0000 & .0000 & .0000 & .0000
\end{tabular}

*Leftists vs. Rightists and Centrists on all Gulf indexes.

Rightists vs. Centrists on IRAQHAWK, USJUST, and IRAQDOVE.

\begin{tabular}{lrrrrr}
\hline Academic Fields & & & & & \\
$\quad$ Business & 3.90 & 3.69 & 2.16 & 1.88 & 0.99 \\
$\quad \begin{array}{l}\text { Science and Math } \\
\text { Education }\end{array}$ & 3.55 & 3.43 & 2.41 & 2.09 & 1.39 \\
$\quad$ Humanities & 3.48 & 3.36 & 2.70 & 2.26 & 1.50 \\
$\quad$ Social Science & 3.11 & 3.13 & 2.89 & 2.45 & 2.38 \\
& 2.95 & 3.15 & 2.94 & 2.45 & 2.91 \\
\hline eta & .27 & .20 & .26 & .24 & .26 \\
F value & 11.49 & 6.22 & 10.32 & 9.56 & 11.09 \\
$\quad$ sig of F & .0000 & .0001 & .0000 & .0000 & .0000
\end{tabular}

*Social Science and Humanities vs. Business on all Gulf indexes.

Social Science and Humanities vs. Science/Math on all Gulf indexes except USJUST. Social Science vs. Education on GULFPROTEST.

\begin{tabular}{lrrrrr}
\hline Age Cohorts & & & & & \\
Pre-Vietnam & 3.47 & 3.42 & 2.34 & 2.18 & 1.53 \\
Vietnam & 3.26 & 3.28 & 2.72 & 2.28 & 2.14 \\
$\begin{array}{l}\text { Post-Vietnam } \\
\text { eta }\end{array}$ & 3.34 & 3.28 & 2.84 & 2.21 & 2.10 \\
F value & .08 & .07 & .14 & .04 & .10 \\
sig of F & 1.82 & 1.39 & 6.42 & 0.40 & 3.02 \\
& .16 & .25 & .0017 & .67 & .05
\end{tabular}

*Pre-Vietnam vs. Vietnam and Post-Vietnam on IRAQDOVE.

\begin{tabular}{lrrrrr}
\hline $\begin{array}{l}\text { Degree Cohorts } \\
\text { Pre-Vietnam }\end{array}$ & 3.50 & 3.51 & 2.34 & 2.18 & 1.53 \\
Vietnam & 3.29 & 3.27 & 2.72 & 2.26 & 2.05 \\
$\begin{array}{c}\text { Post-Vietnam } \\
\text { eta }\end{array}$ & 3.33 & 3.29 & 2.85 & 2.84 & 2.15 \\
F value & .07 & .10 & .16 & .05 & .09 \\
sig of $\mathrm{F}$ & 1.63 & 3.17 & 8.08 & 0.67 & 2.50 \\
& .20 & .04 & .0003 & .52 & .08
\end{tabular}

*Pre-Vietnam vs. Vietnam and Post-Vietnam on IRAQDOVE. 
marginally better than social views as an overall indicator of Gulf attitudes. All political indicators were significantly related to all Gulf indexes at beyond the .0000 level. Eta measures of association ranged from .24 to .55 . The Gulf index mean that consistently showed the lowest eta value for all independent variables was IRAQDOVE, again indicating that faculty were least divided in their assessment of Iraqi justifications for the invasion of Kuwait.

Variations in faculty response on the basis of academic discipline revealed consistent patterns: Business faculty were most supportive of the war on all measures, followed in order by faculty in Science/Math disciplines and then by those in Education. While there were small response variations between Social Science faculty and those in Humanities, the similarities between these two categories were far more apparent than their differences. Collectively, Social Science and Humanities faculty stood apart from the rest of the professoriate: they were significantly less supportive of U.S. military action and justifications (as indicated by IRAQHAWK and USJUST measures), scored higher on IRAQDOVE and IRAQJUST than faculty in other fields, and had substantially higher GULFPROTEST means (especially Social Science faculty). When we cross-tabulated faculty fields by political orientation variables (see Table 7), our findings showed that both Social Science and Humanities professors were significantly more likely to identify with the Democratic Party, vote for the latter's presidential candidate, and express left-liberal views on economic and social issues. Though not quite as strongly related to our Gulf measures as political orientations per se (eta values ranged from .20 to .27 and all were statistically significant at the .0001 level or beyond), it is clear that academic field of training was an important source of variation in both faculty political values and in their reactions to the Persian Gulf War. The importance of the main effects of academic field were evident when we ran two-way ANOVA tests and discovered virtually no significant interaction effects between discipline and either political variables or cohort categories.

Of all the variables examined in this study, faculty cohort categoriesconceptualized with reference to the Vietnam War - proved to be the weakest predictors of faculty attitudes toward the Persian Gulf. Eta values were weak, ranging from only .04 to .16, and corresponding levels of significance generally were in excess of .05. Two-way ANOVA tests did not uncover any meaningful patterns of interaction between cohorts and our other independent variables, nor did simple cross-tabulation show an unequal distribution of cohort groups in different academic fields. 
Table 7. Cross-Tabulation of Academic Disciplines by Political Indicators

\begin{tabular}{|c|c|c|c|c|c|}
\hline & $\begin{array}{c}\text { Social } \\
\text { Science }\end{array}$ & Humanities & Education & $\begin{array}{l}\text { Science } \\
\& \text { Math }\end{array}$ & Business \\
\hline \multicolumn{6}{|l|}{ Political Party } \\
\hline Democrats & $75 \%$ & $72 \%$ & $59 \%$ & $56 \%$ & $43 \%$ \\
\hline Republicans & 11 & 19 & 29 & 33 & 44 \\
\hline Other & 11 & 6 & 7 & 7 & 7 \\
\hline None & 2 & 3 & 5 & 5 & 7 \\
\hline chi square $=46.3$ & $\mathrm{sig}=.00001$ & & & & \\
\hline \multicolumn{6}{|l|}{1988 Vote } \\
\hline Dukakis & $70 \%$ & $62 \%$ & $47 \%$ & $53 \%$ & $37 \%$ \\
\hline Bush & 17 & 28 & 42 & 38 & 58 \\
\hline Other & 8 & 3 & 5 & 5 & 0 \\
\hline None & 5 & 7 & 7 & 4 & 5 \\
\hline chi square $=49.6$ & $\operatorname{sig}=.00000$ & & & & \\
\hline \multicolumn{6}{|l|}{ Economic Views } \\
\hline Leftist & $48 \%$ & $43 \%$ & $20 \%$ & $26 \%$ & $15 \%$ \\
\hline Centrist & 50 & 50 & 64 & 65 & 65 \\
\hline Rightist & 2 & 7 & 16 & 9 & 20 \\
\hline chi square $=54.2$ & $\operatorname{sig}=.00000$ & & & & \\
\hline \multicolumn{6}{|l|}{ Social Views } \\
\hline Leftist & $61 \%$ & $60 \%$ & $36 \%$ & $37 \%$ & $24 \%$ \\
\hline Centrist & 36 & 34 & 46 & 53 & 58 \\
\hline Rightist & 3 & 6 & 18 & 10 & 17 \\
\hline chi square $=54.0$ & $\operatorname{sig}=.00000$ & & & & \\
\hline
\end{tabular}


However, one faculty cohort, whether measured by age criteria or date of academic degrees, did tend to stand out from the others in our sample: namely, the pre-Vietnam cohort, which consistently scored somewhat higher on military support measures and lower on opposition than either the Vietnam or post-Vietnam cohorts. The clearest index differences were shown for GULFPROTEST and especially IRAQDOVE, with pre-Vietnam faculty scoring significantly lower on the latter measure compared to the other two cohort groups. Cross-tabulation of cohort categories with political indicators also revealed that pre-Vietnam faculty were less likely to favor the Democratic party or take left-liberal positions on social-economic issues, and were more likely to have voted for George Bush in 1988 (see Table 8). In contrast, Vietnam and post-Vietnam faculty were virtually indistinguishable in their evaluations of the Persian Gulf War and similar in their political preferences. If anything, the slight differences between the latter two groups suggest that post-Vietnam faculty might have been a little less supportive of U.S. action in the Gulf than the Vietnam cohort. In general, the limited data we have examined in this study do not confirm a picture of a special Vietnam cohort set apart by radically different political views from all other segments of the professoriate.

\section{Discussion}

Just as Vietnam provided a context for Ladd and Lipset's seminal study of ideology in academia, the 1991 Persian Gulf War has provided us a backdrop for sketching a partial political portrait of the contemporary American professoriate. Although the main features of this portrait are only blocked out and suggestive of underlying complexities, we nevertheless are able to see certain fundamental continuities between contemporary political values of professors and value patterns of previous eras. We see, for instance, that the liberal tendencies of college faculties chronicled by Ladd and Lipset for the earlier and middle decades of this century remain in effect. This liberalism is reflected in measures of political party identification, voting behavior, self designated ideological views, and attitudes toward a major international conflict of arms. Furthermore, variations in these measures within the academy are clearly a function of approximately the same disciplinary distinctions noted over twenty years ago by Ladd, Lipset, and others: social science and humanities faculties are the most liberal, while education, math-science, and business faculties are successively less liberal.

Faculty opposition to the war in Vietnam was widespread at the time of Ladd and Lipset's studies in the late sixties and early seventies. At the same time, a majority of Americans also had become disenchanted with the 
Table 8. Cross-Tabulation of Faculty Age Cohorts by Political Indicators

\begin{tabular}{|c|c|c|c|c|}
\hline & & PreVietnam & Vietnam & PostVietnam \\
\hline \multicolumn{5}{|l|}{ Political Party } \\
\hline Democrats & & $60 \%$ & $67 \%$ & $53 \%$ \\
\hline Republicans & & 32 & 21 & 28 \\
\hline Other & & 6 & 7 & 13 \\
\hline None & & 2 & 5 & 6 \\
\hline chi square $=19.2$ & \multicolumn{4}{|l|}{$\operatorname{sig}=.004$} \\
\hline \multicolumn{5}{|l|}{1988 Vote } \\
\hline Dukakis & & $53 \%$ & $60 \%$ & $54 \%$ \\
\hline Bush & & 40 & 31 & 32 \\
\hline Other & & 3 & 5 & 6 \\
\hline None & & 4 & 5 & 9 \\
\hline chi square $=9.9$ & $\operatorname{sig}=.123$ & & & \\
\hline \multicolumn{5}{|l|}{ Economic Views } \\
\hline Leftist & & $28 \%$ & $36 \%$ & $36 \%$ \\
\hline Centrist & & 63 & 57 & 51 \\
\hline Rightist & & 10 & 8 & 13 \\
\hline chi square $=7.0$ & $\operatorname{sig}=.137$ & & & \\
\hline \multicolumn{5}{|l|}{ Social Views } \\
\hline Leftist & & $37 \%$ & $49 \%$ & $53 \%$ \\
\hline Centrist & & 52 & 42 & 37 \\
\hline Rightist & & 11 & 9 & 10 \\
\hline chi square $=10.4$ & $\operatorname{sig}=.034$ & & & \\
\hline
\end{tabular}

war after a decade of increasing divisiveness and civil unrest (cf. Gallup Poll Index Reports \#34 [April 1968] and \#61 [July 1970]). Thus, by 1970, the opinions held by the professoriate and the American public on the issue of perpetuating U.S. involvement in Vietnam no longer contrasted so clearly as they had earlier in the conflict. The brevity of combat and ease of victory in the Persian Gulf, however, was associated with a sharp differentiation of public versus professorial reactions. In January and February of 1991, U.S. 
warmaking against Sadaam Hussein was resoundingly popular with the general American public. In contrast to this massive approval of U.S. war actions in the Persian Gulf, we found only lukewarm support for the war among the professoriate as a whole.

Given the disproportionate number of current faculty who may be counted as members of a Vietnam generation in academia, one might suspect a carry-over of antiwar sentiments among this particular cohort that would account for the largest portion of faculty opposition to U.S. military involvement in the Persian Gulf. However, with results reminiscent of the conclusions drawn by Holsti and Rosenau $(1980,1984,1990)$ in their studies of generational differences among elites, our analysis of data thus far does not support this hypothesis. Holsti and Rosenau's data showed that occupational differences were a greater source of ideological variation than were generational differences; analogously, in our study of academics, variations in academic discipline, and not generational attachments, were linked, systematically, to variations in political preference and attitudes toward the Persian Gulf War.

If an independent cohort effect were operating we would expect the Vietnam generation to be significantly more antiwar than either of the other faculty cohorts. But in fact the Vietnam generation (whether defined as an age cohort or a degree cohort) was not significantly different from the postVietnam generation of faculty in its views of the Gulf crisis. Both Vietnam and post-Vietnam cohorts were less supportive of military solutions than the pre-Vietnam cohort. That the oldest segment of the professoriate expressed the greatest support for the war simply may demonstrate the consequences of aging for status investments by individuals in existing social systems over time, and the subsequent development of more conservative values.

However, we are not yet satisfied that a purely age driven, status development theory of political values (Feuer 1969; Lipset and Ladd 1972; Vern 1974; Ladd 1986) is an adequate explanation of our findings to date. We are currently engaged in processing data obtained from a follow-up survey of our same faculty sample that will allow a more refined analysis of cohort effects. Cohort theories generally assume that the most important factors shaping political views are common generational experiences linked to the dominant events and problems of particular historical periods during which individuals come to maturity (Mannheim 1952; Eisenstadt 1956, 1971; Bass 1974; Ross 1983; Fendrich 1989; McAdam 1989; Kessler 1990). Once formed, generational perspectives tend to persist over time as cohort members' primary political frames of reference. One might argue, for instance, that our current data illustrate this process in the pro-military tendencies of the pre-Vietnam cohort. The relevant frame of reference for 
this group would include World War II, Korea and the Cold War-conflicts in which the exercise of U.S. military power was widely legitimated as a moral responsibility to protect democratic freedoms (Wittkopf 1990). At the same time it may be argued that middle aged faculty of the Vietnam era have not become significantly more conservative over time in comparison to younger faculty precisely because, as a cohort, their political values were shaped in opposition to their government's prosecution of the Vietnam War.

What this case would seem to require, then, is a sub-cohort analysis in which the actual Vietnam era political attitudes and experiences of respondents who were students at that time are differentiated. Those individuals who were strongly opposed to the Vietnam War and/or engaged in protest activities should be distinguished from cohort members who were not politically active, or who supported the war. We suggest the following hypothesis to be tested by an extended analysis of our data in future reports: Those current faculty members who were most opposed to the Vietnam War as students were also those most opposed in 1991 to the Persian Gulf War. This hypothesis acknowledges the fallacy of overgeneralizing about the commonality of a cohort experience while still emphasizing the impact and continuity of values derived from watershed events, such as the Vietnam War, for more cohesively defined sub-cohorts.

This approach also would permit further exploration of the process of political socialization of students on university campuses. For instance, we might hypothesize that current faculty who supported or participated in student demonstrations in the 1960s would be more supportive and encouraging, than other faculty, of student dissent against the deployment of American military forces in the Middle East. Data from our second faculty survey also should allow us to determine whether 1960s-era antiwar activists among the professoriate were relatively intolerant of conservative expressions of support for the Gulf war by students and colleagues. This latter question suggests a partial test of conservative claims that American universities have become hotbeds of leftist controlled restraints on academic freedom ("political correctness") in contemporary higher education (Kimbal 1990; Chronicle of Higher Education 1991, 1, 14-15).

\section{REFERENCES}

Austin, Alexander, Helen Austin, and Allan Bayer. 1975. The Power of Protest: A National Study of Student and Faculty Disruptions With Implications for the Future. San Francisco: JosseyBass.

Barone, Michael and Grant Ujifusa. 1990. The Almanac of American Politics. Washington, DC: National Journal, Inc. 


\section{4 | Gary Shepherd and Gordon Shepherd}

Bass, Allan. 1974. Generational Analysis: Description, Explanation and Theory. Journal of Social Issues 30: 55-72.

Bayer, Allan E. 1971. Institutional Correlates of Faculty Support of Campus Unrest. Washington, DC: American Council on Education. 1974. Teaching Faculty in Academe. New York: McGraw-Hill.

Bengston, Vern. 1974. Time, Aging, and the Continuity of Social Structure: Themes and Issues in Generational Analysis. Journal of Social Issues 30: 1-30.

Carnegie Foundation for the Advancement of Teaching. 1989. The Condition of the Professoriate: Attitudes and Trends. Princeton, NJ: Princeton University Press.

Chronicle of Higher Education. 1991. Vol. 34, No. 12.

Crawford, Alan. 1980. Thunder on the New Right and the Politics of Resentment. New York: Pantheon Books.

Cole, Stephen and Hannelore Adamsons. 1970. Professional Status and Faculty Support of Student Demonstrations. Public Opinion Quarterly 34: 389-394.

Diggins, John Patrick. 1992. The Rise and Fall of the American Left. New York: W.W. Norton.

Dionne, E.J. 1992. Why Americans Hate Politics. New York: Simon and Schuster.

Eisenstadt, S.N. 1956. From Generation to Generation. Glencoe, IL: The Free Press.

. 1971. Generational Conflict and Intellectual Antinomianism. Annals of the American Academy of Political and Social Sciences 395.

Feuer, Louis. 1969. The Conflict of Generations. New York: Basic Books.

Fendrich, James Max. 1989. The Transition From Student to Adult Politics. Social Forces 67: 10491057.

Fuller, Timothy. 1990. The Voice of Liberal Learning. New Haven, CT: Yale University Press.

The Gallup Poll Monthly. 1991 (January, February, March).

Gitlin, Todd. 1987. The Sixties: Years of Hope, Days of Rage. New York: Bantam.

Gless, Darryl and Barbara Hernstein Smith, eds. 1990. The Politics of Liberal Education. Durham, NC: Duke University Press.

Holsti, Ole and James N. Rosenau. 1980. Does Where You Stand Depend on When You Were Born? The Impact of Generation on Post-Vietnam Foreign Policy Beliefs. Public Opinion Quarterly 44: $1-22$.

. 1984. American Leadership in World Affairs: Vietnam and the Breakdown of Consensus. Boston: Allen and Unwin.

1990. The Structure of Foreign Policy Attitudes: American Leaders, 1976-1984. Journal of Politics 52: 94-125.

Kayden, Xandra and Eddie Mahe Jr. 1986. The Party Goes On: The Persistence of the Two Party System in the United States. New York: Basic Books.

Kessler, Lauren. 1990. After All These Years: Sixties Ideas in a Different World. New York: Thunder's Mouth Press.

Kimbal, Roger. 1990. Tenured Radicals: How Politics Has Corrupted the University. New York: Simon and Schuster.

Ladd, Everett and Seymour Martin Lipset. 1975. The Divided Academy: Professors and Politics. New York: McGraw-Hill.

Lazarsfeld, Paul and Wagner Thielens, Jr. 1958. The Academic Mind. Glencoe, IL: The Free Press.

Lipset, Seymour Martin and Richard B. Dobson. 1972. The Intellectual as Critic and Rebel. Daedalus 101: 137-198.

Lipset, Seymour Martin and Everett Ladd. 1972. The Political Future of Activist Generations. In Philip Altbach and Robert Laufer, eds., The New Pilgrims. New York: David McKay Co.

McAdam, Doug. 1989. The Biographical Consequences of Activism. American Sociological Review 54: 744-760.

Mannheim, Karl. 1952. The Problem of Generations. In Essays on the Sociology of Knowledge. London: Routledge and Kegan Paul.

May, Henry. 1963. The Discontent of Intellectuals. Chicago: Rand McNally.

National Center for Education Statistics. 1992. Digest of Education Statistics. Washington, DC (November 10). 
1991. Profiles of Faculty in Higher Education Institutions, 1988. Washington, DC (September 18).

National Faculty Directory. 1991. Detroit: Gale Research, Inc.

Nelson, Michael, ed. 1989. Congressional Quarterly's Guide to the Presidency, 1989. Washington, DC: National Journal, Inc.

Nettl, J.P. 1969. Ideas, Intellectuals, and Structures of Dissent. In Philip Reif, ed., On Intellectuals. New York: Doubleday.

Newman, Stephen L. 1989. Liberalism and the Divided Mind of the American Right. Polity 22: 75-96.

Polsby, Nelson and Aaron Wildavsky. 1988. Presidential Elections. New York: The Free Press.

Ross, Robert. 1983. Generational Change and Primary Groups in a Social Movement. In Jo Freeman, ed., Social Movements of the Sixties and Seventies. New York: Longman.

Sale, Kirkpatrick. 1973. SDS. New York: Random House.

Shils, Edward. 1983. The Academic Ethic. Chicago: University of Chicago Press.

Wills, Garry. 1990. Under God: Religion and American Politics. New York: Simon and Schuster.

Wilson, Logan. 1979. American Academics: Then and Now. New York: Oxford University Press.

Wittkopf, Eugene R. 1990. Faces of Internationalism: Public Opinion and American Foreign Policy. Durham, NC: Duke University Press. 
